$1-1-1890$

\title{
Summary of meteorological observations, and reports of correspondents on conditions of agriculture, etc., in the state
}

John A. Myers

Follow this and additional works at: https://researchrepository.wvu.edu/ wv_agricultural_and_forestry_experiment_station_bulletins

\section{Digital Commons Citation}

Myers, John A., "Summary of meteorological observations, and reports of correspondents on conditions of agriculture, etc., in the state" (1890). West Virginia Agricultural and Forestry Experiment Station Bulletins. 8.

https://researchrepository.wvu.edu/wv_agricultural_and_forestry_experiment_station_bulletins/8 @ WVU. It has been accepted for inclusion in West Virginia Agricultural and Forestry Experiment Station Bulletins by an authorized administrator of The Research Repository @WVU. For more information, please contact ian.harmon@mail.wvu.edu. 
West Virginia University Libraries

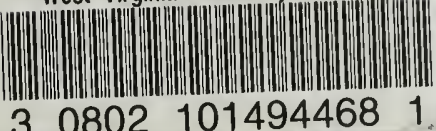





\section{Bulletin No. 8}

OF THE

WEST VIRGINTA

\section{Agricultural Exixperiment Station}

MORGANTOWN, W, VA,

JUNE, 1890.

$-\S-$

SOMMARY OF METEOROLOGICAL OBSERVATIONS, AND REPORTS OF CORRESPONDENTS ON CONDITIONS OF AGRICULTURE. ETC.,

IN THE STATE.

JOEIN A. MITEES.<smiles>[CH]1[CH]C=C1</smiles>

The Director does not hold himself responsible for the individual opinions of the various correspondents. It is hoped to extend the list of correspoidents, so that the station and the public may be informed promptly concerning the prevailing conditions of the weather, crops and stock, in every part of the State.

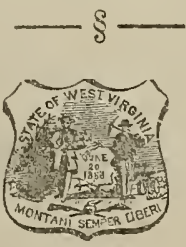

CHARLESTON :

Moses W. Donnalix, Public Printer. 1890. 
BOARD OF REGENTS OF THE WEST VIRGINIA UNIVERSITY

District.

1. J. B. SOMMLRVILLE,

2. CLARENCE L. SMITH,

3. PEREGRIN HAYES,

4. D. D. JOHNSON,

5. JOHN G. SCHILLING.

6. EDWARD A. BENNETT,

7. WIRT A. FRENCH,

8. M. J. KESTER,

9. D. C. GALLAHER,

10. THOMAS J. FARNSWORTH,

11. JOSEPH MORELAND,

12. JOHN A. ROBINSON,

13. DR. W. W. BROWN,
P. O. Address.

Wheeling.

Fairmont.

Glenville.

Long Reach.

Spencer.

Huntington.

Princeton.

Union.

Charleston.

Buckhannon.

Morgantown.

Patterson's Depot.

Kabletown.

MEMBERS OF THE STATION COMMITTEE.

JOHN A. ROBINSON, JOSEPH MORELAND, DR. W. W. BROWN,

Prisident of the University.

E. M. TURNER, LL. D.,
PEREGRIN HAYS, THOMAS J.' FARNSWORTH, JOHN A. MYERS.

Treasurer. JOHN I. HARVEY.

STATION STAFF.

JOHN A. MYERS, Рн. D., A. C. MAGRUDER, B. S. H. R. BALDWIN, Jr., C. F. MILLSPAUGH, M. D.. S. V. MYERS,
Director.

Creamery-man.

Chemist. Botanist. Stenographer. 
INPORT OF W. A. MORGAN.

Sh gpherdstown, Jefferson Co., W. Va.

For month of April, 1890.

Weather more favorable and pleasant than usual, with a heavier average of rainfall. Not cold. Very little snow. The present condition of wheat and grass crops are considerably in advance of the season, and they are looking well all over the county. The present outlook indicates an abundant harvest. Oats are doing well. No barley or buckwheat as a crop sown. Peaches quoted as an entire failure. Apples and cherries look promising. Our stock have come out of the winter in a healthy and vigorous condition, there having been an abundance of provender. Market only moderate. Many hogs were lost during the latter part of the summer of $18 \$ 9$ by disease. Poultry flourishing. Market good. An extensive creamery, pulp mills, manufacture of lime, marble industry, cut stone for building, and bark mills, are the new enterprises of our county.

Wheat, corn and hay form the principal farming industry of of this section. Wheat and corn very remunerative. Hay paying better. Fruit raising, trucking pay well.

The mild and favorable winter and spring have given vegetation an early start, but the agricultural prospects are much depressed by unremunerative prices.

REPORT OF S. R. HANNEN.

Glign Eaton, Marshalu, Co., W. Va.,

For the month of April, 1890.

Weather rather rainy, particularly' during the last week. A little snow fell in the first half of the month.

Corn not planted. Wheat good, about 95 per cent. Oats rather small, average coming up fairly well. Grass good. No barley or buckwheat. Fruit prospect about an average.

Condition of live stock fairly good, with the exception of sheep. Too much rain for them to winter well, and there are not so many kept now as there were prior to $1 \mathrm{~S} 83$. No diseases as far as I have heard. Fair marliet for all except cattle, which 
are low and slow sale. No new enterprise being dereloped, but a blast furnace at Benwood, and the proposed machine shops of the B. \& O. Railroad about to be located at the same place.

The principal industries are raising wheat, hay, corn, oats, potatoes, some millet, and market gardening in the northern part of the county, cheese making and crermaries.

This has been a wool growing county, but fine wool is not paying as well as it formerly did.

Mutton sheep would pay well if introduced, I think.

IIEPORT OF EUGENE BAKER.

Leetown, Tefferson Co, W. Va.

For the month of April, 1890.

More rain than usual. Temperature variable. Some very warm days.

Corn average 9 bbls. per acrs. The wheat very fine. Corn not yet planted.

Grass excellent. All crops will reach the standard. Wheat will average from 20 to 25 bushels. Yeaches all dead.

Cherries badly injured. Grapes, apples, pears and berries O. K.

All kinds of live stock in good condition. Lambs early and large, sell for $\$ 3.75$. No disease at present. There seems to be little demand for stock, especially linrses. Creameries in county have created a small demand for cows.

Shannondale Springs, for thirty years idle, are being rebuilt and will be open to visitors this seasns. 'T'wo planing mills and sash factories; new wheat elevator and rock quarry, stone crushing mill, are now among the latest enterprises of the county.

The principal farming industries are in raising wheat, corn and grass.

Creamery not well developed. Cattle breeding and hog raising profitable.

The spirit of improvement seems slow to move our people, but it is at last beginning to move.

PEPORT OF J. P. HALE.

Charleston, Kanawha Co., W. Va.

For the month of April, 1890 .

Weather very cool. An unusual amount of rain. Do not know how much in inches.

Corn not planted. Oats looking well. Wheat looking well. No barley or buck-wheat raised here. Grass very good. 
Owing to mild winter live stock is in good condition; better than average for the season. No disease attacking them.

Market fully up to the average.

No new enterprises being developed in our county.

Corn, wheat, oats and grass are the principal farming industries. here.

I think the cultivation of tobacco might be found profitable

REPORT OF S. A. HOUSTON.

Pickaway, Monroe Co., W. Va.

For the month of April, 1890.

Weather very bad. Much rain and a little snow.

Wheat below average; injured by late freeze. Oats just up. Meadows not promising. Pasture grass at this time good. ries.

No peaches. Will be, I hope, one-half crcp apples and cher-

Condition of live stock good. No disease prevailing. Market poor. No money in stock raising of any kind, except sheep.

Creamery at Pickaway run one year with reasonable success.

The principal industries are raising stock, catile, sheep, etc.

REPORT OF A. W. WESTFALL,

Auburn, Ritchri Co., W. Va.

For the month of April, 1890.

Plenty of rain during the month, but very little snow. Only three snow-squalls.

No corn growing yet. Wheat in good condition. Oats good. No barley raised in this or adjoining cornties. Grass extra good. No buck-wheat growing. Peaches not one-fourth crop. Apples about three-fourths. Plums and cherries about the same average as apples.

Condition of stock good, especially horses and sheep. Cattle, swine, and poultry fairly good. No contagious diseases among them.

Market good for horses, sheep, swine and poultry. Cattle market not so good.

The principal industries are raising corn, wheat, oate, potatoes: \&c.; also stock raising. Everything in a prosperous condition.

Farmers are realizing good prices for all products. 
REPORT OF CAPT. LEE H. MOLER.

Molers, JefFerson Co., W. VA.

For the month of April, 1800.

It has rained two days out of three during the past month.

Corn not planted. Wheat flourshing. Oats seeded, not up yet. Barley very little sown, but in good condition. Buckwheat, not the season. Grass abundant. Clover not hurt by the freeze.

Fruit killed by frosts, except apples. Cattle in better condition than for years. Horses good. Sheep in excellent shape. Swine thriving, all owing to our mild winter. Ponltry, a pet hobby just here. The sale of eggs and chickens could be made to exceed the corn crop of 1859 at 30 cts. per bushel; $5 \frac{1}{2}$ miles rail road develop. ing, line above iron ore beds. Bark mill, large Hotel at Harper's Ferry for sumwer boarders, etc.

Our industries are varied; corn, wheat and hay with the feeding of cattle engage our attention. Spring lambs bring remunerative prices. We claim to excell in almost evergthing that a good soil will bring forth. There is none other like our Jefferson county.

REPORT OF WM. HAYNES.

Stockyard, Sumuers Co., W. Va.

For the month of April, 1890.

The weather has been very cool, wet and gloomy. Not a very heavy rainfall.

Very little corn planted in this section in April. The wet weather prevented the preparation of corn land and is the same with oats.

The wheat although killed down by the freeze of March, has grown again and is now looking well. Oats late and looking poorly. Grass doing well. Fruit of every kind in this region killed.

All kinds of stock are doing fairly well. No complaint of diseases among them.

Market for horses, cattle and sheep is improving.

We have in our county two strong companies opening quarries of brown stone. They employ quite a number of hands.

All grain crops are profitably grown in this county as well as the grass.

Live stock is raised. This is mainly a mountainous county. Quite an amount of lumbering is done. 
REPORT OF W. G. AND M. D. RILEY.

Elk City, Barbour Co., W. Va.

For the month of April, 1890.

First of the month very wet; large rainfall and a little snow. The last week, weather good.

Wheat looks fine. Will average 95 per cent., compared with other years. Grass is backward, but there is a fine sod.

Fruit was hurt by the freeze in March. Peach trees nearly all killed.

The condition of live stock good. No diseases among them.

Market dull, except for sheep, for which it is good.

Our county does not raise enough to supply the demand for farm products. It is devoted to stock, horses, sheep and cattle.

Our people are much pleased with your efforts in their behalf. Hope you may be able to signal good for the farmer.

REPORT OF R. A. ALEXANDER.

Charlestown, Jefferson, Co., W. Va.

For the month of April, 1890.

Large rainfall.

The wheat more advanced and promising than for years.

Oats well advanced. Grass very fine.

Fruit not over three-fourths of a crop promised.

Cattle rather scarce and commanding a fair price. Horses in fine condition, selling at good prices. Sheep high.

Poultry scarce and high.

A bark-mill for grinding bark and extracting juice, established 1889 , is the largest enterprise developed in our county.

Wheat and corn seem to be the only thing our farmers care to raise for market.

The season is well advanced and the farmers are doing well with their work.

REPORT OF GEO, T. ZGBERT.

Raven's Eye, Fayetre Co., W. Va.

For the month of April, 1890.

A considerable amount of rain and several snow squalls.

About half of the oats sown.

Grass excellent.

Live stock of all kinds in better condition than usual, owing to the open winter. 
Market, except for sheep, very dull.

Stock raising and general farming are the principal industries. Our county is well adapted to sheep husbandry.

REPORT OF W. C. KISEN.

Franklin, Pendleton Co., W. Va.

For the month of April, 1890.

Weather very rainy and a little snow.

Corn is just being planted.

Wheat is looking fine; promises more than an average crop. There is not a large acreage of oats sown. It looks well for the time of the year. No barley raised, and buckweat is not sown yet.

The condition of oattle moderately good. Some young ones have died from what we term "scowers." Horses in good condition. Market low. Sheep in good condition. Market good. Swine are looking well, but they are scarce. Cholera among poultry in some parts of county.

No new enterprise is being developed.

Stock raising is the principal industry. Corn and wheat are raised in considerable quantities.

REPORI OF J. W. CARDER.

Pleasant Dale, Hampshire Co., W. Va.

For the month of April, 1890.

The weather has been conl and rainy. Quantity of rain above the average. No snow.

Condition of wheat good, considerably above the average for this month.

Grass doing finely. Very little corn planted \&s yet. Barley, none raised here. Prospects for fruit very unfavorable.

Condition of stock good. No disease prevalent. Market for sheep and swine brisk. Horses mediam. Cattle very dull.

No new enterprise being developed.

Producing wheat, rye, corn, oats and buck-wheat, are the principal farming industries. Stock is raised.

BEPORT OF ADAM FISHER.

Moorefield, Hardy Co., W. Va.

For the month of April, 1890.

The weather has been very wet and cool. No snow. I can not give quantity of rain and snow, as I have no rain guage. 
Prospect for corn not flattering. Wheat and oats very promising. No barley. Pasture and meadows look extra well.

Condition of stock good, owing to the mild winter. Very little attention paid to poultry, too far from railroad.

Market has an upward tendency for stock generally.

Tan-bark and timber are the latest and most actively pursued enterprises in this county.

The principal farming industries are cultivating corn, wheat and grass in the valley. Oats and buck-wheat on the hills.

Moorefield, our county seat, is twenty-seven miles from a railroad and has a population of about 600 .

REPORT OF M. S. BRYTE.

Bruceton Mills, Preston Co., W. Va.

For the month of April, 1890.

Weather has been very rainy during entire month. A little snow first part of April.

Wheat and grass in good condition. Prospect very good. The rainy weather will interfere with the sowing of oats. Fruits of all kinds badly injured. There will be some cherries and apples. It is feared that the peach trees have been killed in various localities.

Owing to the abundance of feed and the open winter stock of all kinds are in good condition. No diseases reported among them. Farmers complain of the ravage of cholera, especially among chickens.

Market fairly good, with prices ranging low.

A creamery at Terry Alta, and perhaps other points in the county, are the latest enterprises. The principal industries are in raising wheat, corn, rye, buckwheat, oats, grais, sorghum and potatoes. Fruits of all kinds, poultry, butter and eggs are produced.

REPORT OF W. G. AND M. D. HILEY.

Elk Citr, Barbour Co., W. Va.

For the month of May, 1890.

Weather cold and wet. Large amount of rain.

Wheat locks fine (95 per ct.). Meadows fine (100 per ct.). Sod was never better. Not many apnles and not much small fruit.

Condition of live stock fine. Market horses dull; cattle same; sheep good. A number of the best cattle in the county have been engaged at $3 \frac{1}{4}$ to 4 cts. per pound, to be delivered in August and September.

Wheat, corn, oats and stock raising are the principal industries. 
REPORT OF S. A. HOUSTON.

Pickaway, Monroe Co., W. Va.

For the month of May, 1890.

Considerable rain, but no snow. Corn fair. Wheat below average. Oats fair. No barley sown. No buckwheat sown. Grass good.

Condition of live stock good. No disease. Market rather on upward tendency.

New enterprises, one creamery.

Stock raising is the principal industry. Too far from market for anything else.

We need above all things a reduction of the tariff, and free coinage of silver.

REPORT OF W. C. KISEY.

Franklin, Pendleton, Co., W. Va.

For the month of May, 1890 ,

An unusual quantity of rain. Weather warm.

Corn is beginning to lnok well. The prospect for wheat has not changed since last month. No barley.

Oats are looking well and promise a fine crop. Buckwheat not planted yet.

.Condition of live stock good. No diseases. Market poor, with the exception of sheep, which are bringing fair prices.

Stock raising is the principal industry, although there is considerable wheat and corn raised.

With railroad facilicies, dairying would be profitable.

KEPORT OF J. W. CARTER.

Pleasant Dale, Hampshire Co., W. Va.

For the month of May, 1893.

Very wet and rather cool.

Corn a good acreage planted. Wheat above the average. Oats doing nicely. Grass good, prospects for a heavy crop.

No peaches; apples, prospect poor for half crop. Cherries very few.

Condition of cattle good. Market flat. Horses, condition good, local demand good for "No. 1" work horses.

Sheep market very active, quantity limited. Swine scarce, market good.

Poultry-too much wet weather, causing "gapes" in young; some cholera reported. 
REPORT OF CAPT. LEE H. MOLER.

Moler's, Jefferson Co., W. Va.

For the month of May, 1890.

Rainy, only nine (9) clear days in the month.

Wheat "barring accidents" will make a good yield. Nights too cool for corn. Oats slightly rusted. Grass abundant.

Fruit in a manner killed.

Condition of live stock fine, owing to rank growth of blue grass No diseases as yet; prices are off.

New enterprises, are $5 \frac{1}{2}$ miles railroad, with limestone quarries. also connection to paying ore deposits.

Sheep and lambs, with the product of the hen houses, pay better than all other industries.

Jefferson county is really the garden spot of the world. Would like to know from whence the army-worm cometh and what is his paternity.

RIPORT OF GEO. T. EGBERT.

Ravens Eye, Fayette Co., W. Va.

For the month of May, 1890.

We have had a great quantity of rain.

The farmers are just finishing their corn planting, oats not as good as usual. Some late grass excellent. One fourth crop of apples would be a large estimate. Cherries good. Peach trees all killed.

Condition of live stock exceptionally good and free from disease.

Market, except for sheep, very dull, a few of the later changing hands at good prices.

\section{REPORT OF ADAM FISHER.}

Moorefield, Hardy Co., W. Va.

For the month of May, 1890.

Exceedingly wet, more rain than in April.

Corn getting through. Wheat beginning to rust. Oats damaged too, by wet weather. No barley or buckheat. Grass more abundant than ever before. No fruit, average uncertain.

Condition of live stock good, no disease among them. Not much attention paid to poultry. Markets generally improving.

Some prospecting for ore is a new enterprise in our county.

Corn and wheat, with stock raising are the principal industries. Hore breeding on the increase.

If the rains continue much longer grain farming will be a failure. 
REPORT OF J. P. HALE.

Charleston, Kanawha Co., W. Va.

For the month of May, 1890.

Corl for the season. A great deal of rain. No snow.

Corn just planted. Very late owing to wet weather. Wheat not looking well. Will not be over two-thirds of a crop. Oats not very promising. No barley. No buckwheat.

Grass looking very fine.

Condition of stock fairly good. Some diseases among cattle attributed to the mild winter, followed by the very wet and cold spring.

Market for stock good.

A furniture factory is the latest enterprise developed in our county. Some saw-mill extensions in the county also.

Corn, wheat, oats and grass are the principal farming industries.

Fruit culture is being extended and it is believed there is good promise in it.

The general health is good, as usual.

REPORT OF R. A. ALEXANDER.

Charlestown, Jefferson Co., W. Va.

For the month of May, 1890.

We have had excessive amount of rain during the month.

Corn and oats promise weli. Grass very fine. Wheat thick on ground, but the heads are not as long and full as they might be. The fruit crop will not be over one-fourth of what it usually is.

Stock in fine condition. No disease. Cattle looking up. Horses dull. Sheep and lambs high. Swine good prices.

We have started an improvement company here and Harper's Ferry, and our people are alive and fully up to the times, and the movement toward building, etc.

The principal farming industries in our county are, wheat, corn, oats and cattle.

Our farmers by good management have been working out of debt, and are in good shape.

REPORT OF A. W. WESTFALL.

Auburn, Ritchie Co.. W. Va.

For the month of May, 1890.

No snow. Plenty of rain, averaging at least three days during each week. Corn not very good on account of too much rain. 
Wheat very good. Grass in large quantities, but not of good quality.

Peaches entire failure. Apples and various other fruits about a three-fourths crop.

Condition of stock very good, especially sheep. Market for horeses and sheep remarkably good, while cattle, swine and poultry very indifferent. No disease prevalent.

No new enterprise being developed. Stock and grain raising is the principal farming industry. Lumber business is carried on extensively. General business outlook good.

REPORT OF WM. HAYNES.

Stock Yards, Sumners Co., W. Va. For month of May, 1890.

Frequent rains have fallen, but with small amount of rainfall. Days warm, nights a little cool. The weather has been good for corn, which is doing well.

Wheat is doing fairly well. Late wheat is rather light. Oats very late. Fow fields look well. Grass very fine. No fruit. Live stock are doing well, no diseases. Market poor.

No new enterprises except those mentioned in last report. Stock raising is the leading industry. Grass and grain crops grow well. A large amount of staves and lumber has been cut in this county.

REPort of Eugene Baker.

LeETown, JefFerson Co., W. VA.

For the month of May, 1890.

Very rainy. Terrific hail and wind storm on May 3rd., swept every thing in its course.

Corn delayed by wet weather. Wheat very fine. Oats good. Grass excellent. No peaches, few charries and pears. No apricots. Plenty of berries, from present outlook, I think. Wheat will average 25 bushels per arce in this county, except in the track of the storm of May 3rd., where not a grain will be made.

Live stock in good condition. No diseases. Market low.

Lambs from $\$ 3.50$ to $\$ 4.25$, according to size. Wool 25 to 27 cents a pound.

Hogs low, also cattle. No market for horses.

Charslestown is on a big boom. Expect to have many new enterprises soon. Will report them in my next.

The principal farming industries are wheat, corn and grass.

The storm spoken of, passed over the north end of this county, taking in Middleway and Summit Point. Wheat, corn, grass, trees, buildings, \&c., destroyed to the amount of $\$ 10,000$. Wind travelled at rate of sixty miles an hour. 
REPORT OF S. R. HANEN.

Glen Easton, Marseall Co., W. Va.

For the month of May, 1890.

No stnow, but an inprecedented amount of rain.

Corn not all planted on acount of rain. Wheat promises a full crop, or say 98 per cent at least.

Oats a full crop. No barley raised. No Buckwheat. Grass good.

Fruit will average half crop.

Condition of live stock good. No diseases, as far as I have been able to ascertain.

Sheep, fair condition, but they did not winter well on account of excessive rain during winter months.

Several wells have been bored for oil. No reports from them yet.

Grass, wheat, corn, oats, and potatoes with market gardening are the principal farming industries here.

A woolen mill would pay.

REPORT OF W. A. MORGAN.

Shepherdstown, Jefferson Co., W. VA.

For the month of May, 1890.

An unusual amount of rainfall, beginning the 15 th and continuing to the 26th. No snow.

Corn is coming up well, looks healthy and vigorous.

Wheat crop generally very promising ant heading well, an un. usually large growth. Oats growing rapidly and looking well. Grass crop very luxuriant and promising, a heavy yield of clover timothy and orchard grass.

Horses and cattle in excellent condition, also sheep and swine healthy and thifty. Poultry interest much looked after. and largely engaged in.

No disease among live stock at present. Market for cattle im. proving. Sheep and poultry in demand.

Paper mills, bark mills, flouring mills, lime kilns, building stone cutting, a McAdamized road being constructed, the finest in the county. Fruit tree nurserios, etc., are the new enterpries being developed in our county.

Wheat, corn, oats, hay, potatoes, poultry, fruit and stock are the principal industries of our county.

Our county is now looking beautiful with its fine fields of luxuriant wheat and blooming meadows, \&c. 
REPORT OF WM. HAYNES.

Stock Yards, Summers Co., W. VA.

For the month of June, 1890.

The weather has been very dry and hot during this month. Crops are suffering for rain.

Wheat is regarded as only a half crop. Corn needs rain; looks badly. Oats and grass drying up. Hay crop tolerably good. No fruit.

Condition of live stock very good. No new enterpises being developed. Stock raising is the principal farming industry. Any grain or grass grows well in this locality.

REPORT OF R. A, ALEXANDER.

Charlestown, Jefferson Co., W. VA.

For the month of June, 1890.

There has been considerable rain fall this month.

Good prospect for corn. Wheat some little scab, but on the whole good. We had a hail-storm that destroyed in the Kabletown and Middleway District at least, 1,000 acres entirely, and damaged badly 1,500. Very little oats. No barley or buckwheat. Grass fine. Very little fruit.

Live stock in fine condition with a fair market.

We have formed a Land and Improvement Company here, with good prospects.

Iron-ore and lime-stone are being developed in our county.

Wheat and corn, and now more attention to grass, (hay). Sheep have been most profitable and the number will be largely increased this year. These are the principal farming industries.

If we had escaped hail this year, aside from fruit, (1890) would have been our most prosperous year in the last ten.

REPORT OF ADAM FISHER.

Mcorefield, Hardy Co., W. Va.

For the month of June, 1890.

The rains continue, but are not now so frequent.

Corn looks promising. Wheat improved. Oats rather indifferent. No barley. No buckwheat. Grass unusually abundant.

Cattle, horses, sheep and swine all in good condition. No attention paid to poultry. No diseases among them. Market fluctuating.

No new enterprises being developed. Stock raising and grain 
of the common kinds, and grass, are the principal farming industries.

Cattle feeding has been the leading business of the farmer. Horse breeding has increased of late.

REPORT OF W. C. KISEN.

Franklin, Pendiet on Co., W. Va.

For the month of June, 18 c 0 .

There has been large quantities of rain this month.

Corn short for time of year. Wheat is affected with rust and scab, will fall below average. Oats do not look well all over the county. Buckwheat just sowed. Grass good.

Live stock in good coudition. No diseases. Market dull for all but sheep.

No new enterprisas being developed. Stock raising, wheat and corn are the principal farming industries.

Dairying might be made profitable, and I have no doubt would, if we had a railroad.

REPORT OF J. W. CARTER.

Pleasant Dale, Hampshire Co., W. Va.

For the month of June, $1 \& 90$.

Weather warm and wet. Have had about double the quantity of rain we generally have in this month.

To talke 100 as an average corn will be 100 , wheat 125 , oats 100 , grass 125 and fruit crop about 10, buckwheat not yet sown.

live stock in good condition. Market for cattle very fiat. Horses steady but not brisk. Sheep high, very active. Swine scarce and prices strong, not many changing hands. Poultry market good, the crop of young supposed to be light.

Producing wheat, rye, oats and corn are the principal farming industries and also stock raising.

RKPORT OF EUGENE BAKER.

Leetown, Jefferson, Co., W. Va.

For the month of June, 1890.

Weather warm, not much rain, but sufficient for crops. Hail and wind upon two occasions.

Corn doing well, rather late. Oats very poor. Wheat good, some scab and a little rust. Oats will be nearly all cut by July 
1st, some complain of blight. Crop will average 15 bushels. Grass fine, very little cut up to this time.

Horses and sheep in good order, Texas Fly very bad on cattle, cholera appearing in swine. Market low and small demand. Butter from 6 to $10 \mathrm{cts}$ per. pound. Milk $30 \mathrm{cts}$. cwt. Boom at Charlestown, expect to open mines, factories, railroads, \&c.

The "Farmers Alliance" is making good headway in our county. Its effects are plainly visible. Brought binder twine from 18 to ]4 cte. per pound, \&c.

REPORT OF W. A. MORGAN.

Shepherdstown, Jefferson Co., W. Va.

For the month of June, 1890.

Early part of month very wet. May 30 , a terrible and very destructive wind and hail-storm through the county a track of about two miles wide, entirely destroying all crops and garcens and demolishing many buildings, trees, etc.

Corn growing finely. Wheat now being harrested, generally a very good crop; well headed and filled and standing erect. Oats growing well. A rery heavy crop of clover and timothy. Little barley raised and no buckwheat. From present appear. ances wheat will average 15 bushels per acre, and grass from one and $a$ half to one and three-fourths tons per acre.

Live stock in gocd condition. No diseases reported. Poultry plentiful and well grown. Market for cattle good and improving for beef and mutton. Sheep and lambs scarce and in good demand at good prices.

Wheat.corn, oats and potatoes are the principal industries; and fruit, trucking, dairying and poultry could be made profitable. Our entire county with the exception of the storm swept district present a beautiful and luxuriant appearance.

KEPOR' OF LEE H. MOLER.

Moler's, Jefferson, Co., W. Va.

For the month of June, 1830.

Weather has been good. Not much of a rain fall.

Corn, gnod stand, and growing finely. Wheat damaged by cab. Oats not one-half cuop; rusted badly. Grass abundant. Fruit crop a failure, excrpt in some small sections.

Cattle in very fine order. Hrirses good; large number of colts this spring. Sheep are in demand. Ewine so far not attacked by cholera. Poultry in the immediate section is more valuable than corn. Some few cases of chclera. No sales made at this period.

Land companies bare been organized in Charlestown with quite a boom.

The principal farming industries are wheat, corn and hay, with an increase in sheep husbandry each year.

Began harvesting to day, the 19th. Wheat stands well. 
REPORT OF J. P. HALE.

Charleston, Kanawha Co., W. Va.

For the month of June, 1890.

The average temperature of the month has been unusually high. More rain than usual for June.

Corn. Fair, wheat light. Oates light. No Barley. Grass good. Fruit almost a failure.

Some "foot evil" among cattle .Horses, sheep and swine in good condition. Poultry all right.

Street railway being constructed in Charleston. Bridge across Kanawha river under contract.

The principal farming industries are wheat, corn and oats.

REPORT OF GEO. T. EGBERT.

Ravens Eye, Fayetée Co., W. Va.

For the month of June, 1890.

We have had frequent showers this month.

Corn promising. Prospect for an oats crop very poor. Grass very fine.

Fruit almost a total failure.

Live stock in good condition. Market very dull, except for sheep, and they are in demand.

No new enterprises are being developed in our county.

KEPORT OF W. G. AND M. D. RILEY.

Elk City, Barbour Co., W. VA.

For the month June, 1890.

Weather warm and wet. Too much rain for farming purposes.

Corn looks well, has been too wet for clean cultivation, average about 95 per cent. Too wet for wheat, not filled well, 75 per cent. Oats look well, about 95 per cent. Grass fine, about 100 per cent. Very little fruit, 25 per cent.

The condition of live stock is good. No diseases among them. Cattle dull sale, horses bad, but sheep find a ready market. Boring for oil at Philippi is the only new enterprise being developed in our county. Stock raising is the principal farming industry.

The depreciation of land in the last ten years has been from 30 to 40 per cent But little is made by farmers generally.

REPORT OF A. W. WESTFALL.

Auburn, Ritchie Co.. W. VA

For the month of May, 1890.

The weather has been rainy, averaging two days per week.

Corn very good. Wheat fair to medium. Uats looking very well. Grass better than it has been for years. Outlook for fruit not guod. Stock in good condition. Market very good, especixlly sheep and poultry. No diseases attacking them. No new enterprises being developed. Raising stock and the various grains are the principal farming industries. Every thing in a prosperous condition. 


\section{METEOROLOGIOAL OBSERVATIONS.}

Summary of Observations taken at the West Virginia Agricultural Experiment Station at Morgantown, beginning October 10, 1888 and ending June, 1, 1889.

\begin{tabular}{|c|c|c|c|c|c|c|c|c|c|}
\hline $\begin{array}{l}\text { BAROMETER, } \\
\text { Reduced to Freezing Point for Oc- } \\
\text { tober November and December. }\end{array}$ & 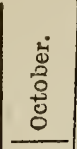 & 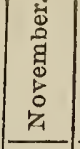 & 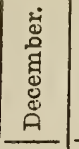 & 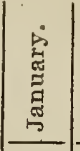 & 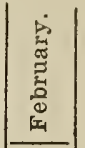 & 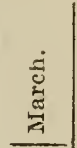 & $\begin{array}{l}\overrightarrow{\tilde{L}_{4}} \\
\overline{4}\end{array}$ & 恕 & $\Xi_{0}$ \\
\hline Mean of morning observations...... & 29.112 & 29.199 & 29.131 & 29.086 & 28.159 & 29.045 & 29.107 & 29.13 & \\
\hline & 29061 & $29 \begin{array}{ll}2 & 141\end{array} \mid$ & 29090 & 29.060 & 29.169 & 29.026 & $|.9 .105|$ & $29.11^{2}$ & \\
\hline Mean of e & 29073 & 29.165 & 29102 & 290181 & 29.180 & $29.0 \div 2$ & 29.126 & 29116 & \\
\hline Mean of a & $29 \cup 82$ & 29.168 & 29.108 & 29.076 & 29.169 & 29.034 & $29 \cdot 113$ & 29.120 & \\
\hline Higl & 29.365 & 29.535 & 29.496 & 29.450 & 29.675 & 29.450 & 29.500 & $\left|\begin{array}{l}20.4001 \\
29.420\end{array}\right|$ & \\
\hline Lowest reading........ & 28713 & 28.717 & $28.447 \mid$ & 28.225 & 28.510 & $\left|\begin{array}{l}28.400 \\
28.555\end{array}\right|$ & $|28.630|$ & $\mid \begin{array}{l}28.800 \\
28.800\end{array}$ & \\
\hline 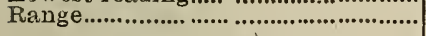 & .652 & .818 & 1.049 & 1225 & 1.175 & .895 & .870 & $\begin{array}{r}.000 \\
\end{array}$ & \\
\hline THERMOMETER. & & & & & & & & & \\
\hline Meau of morning ob & 455 & 40.4 & 37.5 & 315 & 26.3 & 34.5 & 45.8 & $5 \overline{8} .3$ & \\
\hline & 577 & 51.9 & 40.4 & 40.8 & 34.5 & $\begin{array}{l}-1 \\
48.6 \\
48.3\end{array}$ & 59.6 & 70.6 & \\
\hline Mean of eve & 50.2 & 448 & 34.8 & 358 & 299 & 43.5 & 52.8 & 628 & \\
\hline Mean of all observatio & 51.1 & 45.7 & 35,2 & 36.0 & 30.2 & 42.2 & 52.7 & 63.6 & \\
\hline REGISTERING THERMOMETER. & & & & & & & & & \\
\hline 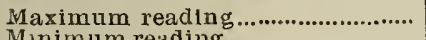 & 76 & 76 & 69 & 60 & 55 & 69 & 84 & & \\
\hline i......... & $\begin{array}{r}32 \\
501\end{array}$ & $\begin{array}{r}22 \\
545\end{array}$ & 6 & 16 & 4 & & & & \\
\hline$\cdots \cdots$ & $\begin{array}{l}59.1 \\
42.2\end{array}$ & $\begin{array}{l}54.5 \\
37.1\end{array}$ & $\begin{aligned} 42 \\
28\end{aligned}$ & $\begin{array}{ll}43 & 8 \\
29 & 7\end{array}$ & $\begin{array}{c}36.9 \\
23.2\end{array}$ & 51.1 & 666 & 734 & \\
\hline 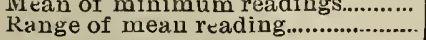 & $\begin{array}{l}42.2 \\
16.9\end{array}$ & $\begin{array}{l}37.1 \\
17.4\end{array}$ & $\begin{array}{r}28 \\
14.3\end{array}$ & $\begin{array}{ll}29 & 7 \\
13 & 8\end{array}$ & $\begin{array}{l}23.2 \\
13.7\end{array}$ & $\begin{array}{l}33.4 \\
17.7\end{array}$ & $\begin{array}{l}428 \\
19.5\end{array}$ & $\begin{array}{r}522 \\
2 \pm .2\end{array}$ & \\
\hline HYGROMETER. & & & & & & & & & \\
\hline Mean relative humidity of morn- & & & & & & & & & \\
\hline idity of after- & 88 & 85 & . & & & 83.6 & 83.9 & 83.4 & \\
\hline . & 70 & 75 & & & & 75.7 & 71.6 & 69.9 & \\
\hline aidity of evening & 10 & 80 & & & & 10.0 & & & \\
\hline midity of all ob- & 84 & 33 & & & & 82.5 & 78.0 & 82.4 & \\
\hline $\begin{array}{l}\text { Mean relative huin } \\
\text { servations.......... }\end{array}$ & 80 & 81 & & & & 80.6 & 77.8 & 78.6 & \\
\hline CLOUDS. & & & & & & & & & \\
\hline Mean cloudiness of morning ob- & & & & & & & & & \\
\hline 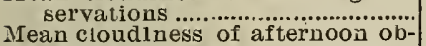 & & 70 & 76.5 & 74.7 & 85.7 & 62.2 & 51.2 & 59.3 & \\
\hline servatiuns............................. & & 59 & 62,6 & 59.1 & 56.4 & 62.3 & 59.5 & 60.3 & \\
\hline $\begin{array}{l}\text { Mean cloudiness of } \mathrm{e} \\
\text { vations....................... }\end{array}$ & & & & & & & 57.2 & 50.7 & \\
\hline Mean cloudiness of all observations & & $\begin{array}{l}56.0 \\
61.9\end{array}$ & 67.4 & $\begin{array}{ll}58 & 1 \\
63 & 9\end{array}$ & $\begin{array}{l}56.4 \\
66.2\end{array}$ & 63.7 & 55.9 & 56.8 & \\
\hline ANEMOMETER. & & & & & & & & & \\
\hline Total number of mile & & & & 4642 & 5391 & 3820 & 4435 & 3166 & 2780 \\
\hline d & & & & & & & & & \\
\hline Average veloc & & ... & ......... & 1498 & $\mid \begin{array}{r}192.5 \\
8.02\end{array}$ & $\mid \begin{array}{r}123.3 \\
5\end{array}$ & $\left|\begin{array}{rr}147.8 \\
6 & 16\end{array}\right|$ & $\begin{array}{r}102.1 \\
4.24\end{array}$ & $\begin{array}{l}92.7 \\
3.86\end{array}$ \\
\hline Prevailing direction............................ & s. W & s. W. & S. W. W. & 3. W. & s. W. & S. W. S & S. W. & S. W & 3.6 \\
\hline PRECIPITATION. & & & & & & & & & \\
\hline Number of das & 14 & 15 & & 13 & 6 & 11 & 12 & 13 & \\
\hline 11 & & & & & & & & & \\
\hline Total precip & & 391 & 1.21 & 2.82 & 2.88 & 3.31 & 4.82 & 5.36 & \\
\hline WEATHER. & & & & & & & & & \\
\hline Number of observations when the & & & & & & & & & \\
\hline & $\ldots$ & ........ & & 21 & 15 & 13 & 21. & 19 & \\
\hline 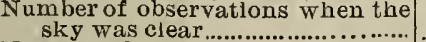 & ........ & & & 15 & 2 & 15 & 10 & & \\
\hline Num & & & & & & & & & \\
\hline $\begin{array}{l}\text { sky was medium. } \\
\text { imber of observatic }\end{array}$ & & & & & 5 & 9 & & 17 . & \\
\hline & . . & & 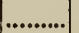 & 3 & 10 & 4 & 5 & 1 & \\
\hline Number of observ & & & & & I & 8 & 11) & 19) & \\
\hline $\begin{array}{l}\text { sky was overc } \\
\text { Number of obser }\end{array}$ & & & & & & & & & \\
\hline sky was covered........................... & .......... & |......... & $|. . . . . . .|$. & 42 & $37^{1}$ & 36 & 28 & 25] & \\
\hline
\end{tabular}




\section{METEROLGGICAL OBSERVATIONS.}

Summary of Otservations talien at the West Virginia Agricultural Lxperiment Station, at MLrgantown, beyinning March 1, 1890 , and ending June 30, 1891).

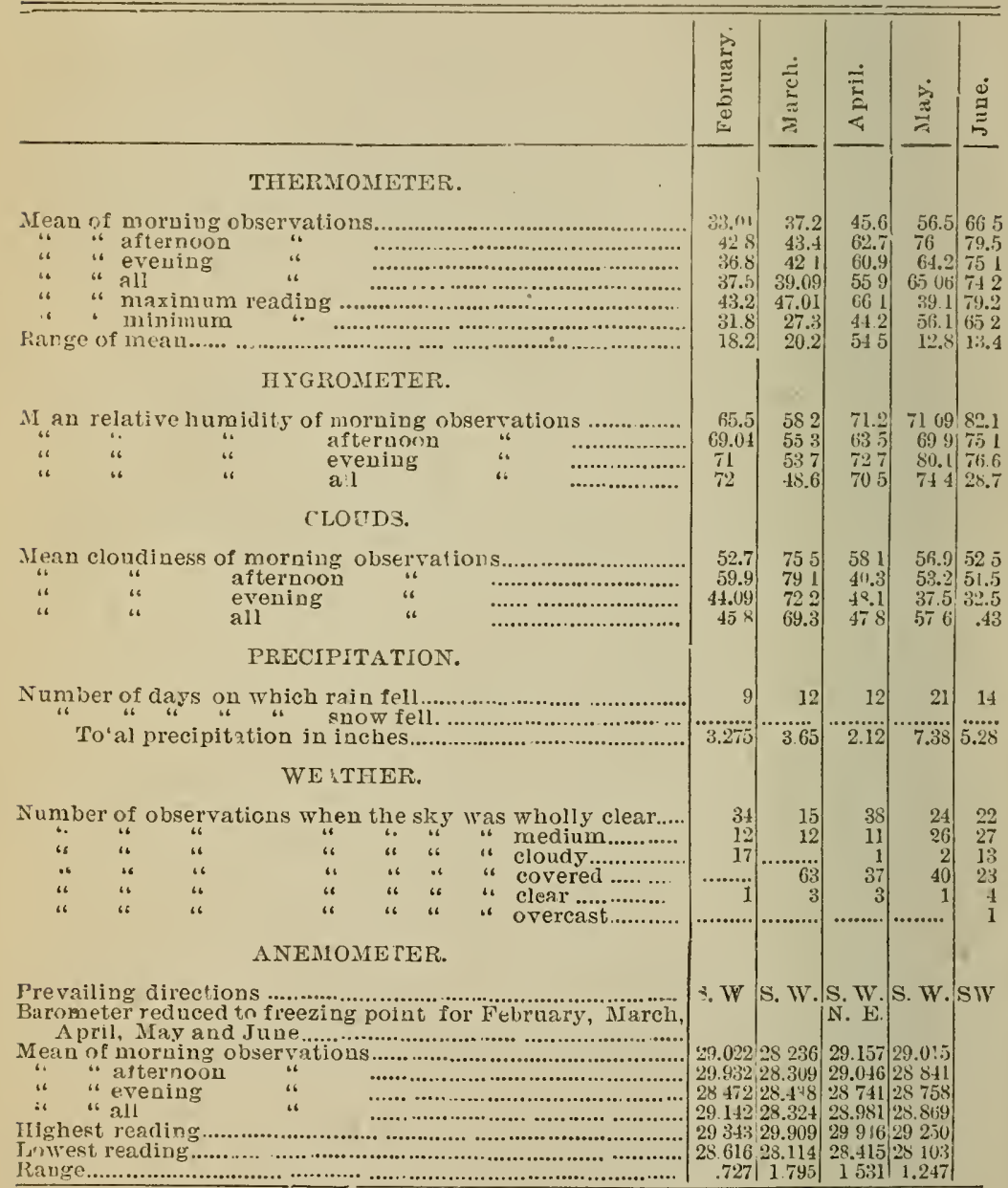





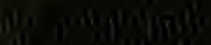
(1) 1 